\title{
The Impact of CdS Nanoparticles on Ploidy and DNA Damage of Rucola (Eruca sativa Mill.) Plants
}

\author{
Inese Kokina, ${ }^{1}$ Inese Jahundoviča, ${ }^{1}$ Ilona Mickeviča, ${ }^{1}$ Eriks Sledevskis, ${ }^{1}$ Andrejs Ogurcovs, ${ }^{1}$ \\ Boris Polyakov, ${ }^{2}$ Marija Jermaļonoka, ${ }^{1}$ Jānis Strautiņš, ${ }^{1}$ and Vjaceslavs Gerbrederss ${ }^{1}$ \\ ${ }^{1}$ Institute of Life Sciences and Technologies, Daugavpils University, Parādes 1a, Daugavpils LV-5401, Latvia \\ ${ }^{2}$ Institute of Solid State Physics, University of Latvia, Kengaraga 8, Rīga LV-1063, Latvia \\ Correspondence should be addressed to Inese Kokina; inese.kokina@du.lv
}

Received 20 July 2015; Revised 4 November 2015; Accepted 9 November 2015

Academic Editor: Subrata Kundu

Copyright (C) 2015 Inese Kokina et al. This is an open access article distributed under the Creative Commons Attribution License, which permits unrestricted use, distribution, and reproduction in any medium, provided the original work is properly cited.

\begin{abstract}
The genotoxic effect of cadmium sulfide nanoparticles (CdS NPs) of different sizes in rucola (Eruca sativa Mill.) plants was assessed. It was confirmed that nanoparticles $<5 \mathrm{~nm}$ in size were more toxic than larger particles at an identical mass concentration. Significant differences in cell ploidy, as well as in the mitotic index, were detected between control and treated samples. Differences in the DNA banding pattern between control samples and samples after treatment with cadmium sulfide nanoparticles were significant and detected at different places as the appearance or elimination of DNA fragments. Fluorescence images showed that cadmium sulfide nanoparticles smaller than $5 \mathrm{~nm}$ in size can diffuse through the membrane and their presence affects the genetic system of the plant.
\end{abstract}

\section{Introduction}

Different nanoparticles (NPs) have a huge potential for biological, biomedical, and environmental applications such as drug targeting, tissue repair, and cell tissue targeting [1]. Among others, semiconductor NPs, including cadmium sulfide (CdS), are of great interest for both fundamental research and industrial development [2]. Additionally, CdS nanoparticles of different sizes and shapes are important for their applications in the optical devices, electronics, and the biomedical and biotechnology fields [3]. Different parts of plants and plant calluses are used to synthesize different NPs from metals such as gold, silver, platinum, zinc, copper, titanium oxide, magnetite, and nickel [4].

Study shows that plant cells accumulate CdSe/ZnS QDs in the cytosol and nucleus and cytotoxicity increases in a dose dependent manner [5]. Subsequently, it was demonstrated that both the DNA repair genes and the ROS scavenging mechanisms are activated within CdSe/ZnS QDs in plant cells [6]. Furthermore, in 2014 Prasad et al. [7] presented their research on DNA damage analyses and revealed that synthesized NPs of CdS QDs caused DNA damage and cell death of lymphocytes.
Although previous studies highlighted the potential environmental and health hazards caused by NPs [8], their activity in plant cells is not well documented. Recently, it was demonstrated that low doses of different types of carbon nanotubes penetrate seed coats and activate seed germination and plant growth [9]. The ability of higher aquatic plants to take up and translocate CdS quantum dots has been shown [10]. Moreover, in previous experiments, it was indicated that the presence of $\mathrm{Cd}$ in culture media results in modifications in the plastid membranes of wheat calluses; all lipid fractions extracted from the plastid envelopes of Cd-stressed plants contained more saturated lipids in comparison to the control $[11,12]$. On the basis of other studies with Arabidopsis thaliana L., the uptake of CdS NPs appears to be limited, because surface modifications arose and specific plant receptors that promote uptake were upregulated [13].

There have been numerous in vivo and in vitro studies showing that NPs cause damage to DNA [14]. The genotoxic potential of silver nanoparticles in increasing concentrations was evaluated in DNA fragmentation studies using plasmid DNA [15]. Clearly fragmented DNA was observed in both silver and gold nanoparticle-treated human breast cancer 
cells [16]. DNA damage, which is a predisposing factor in carcinogenesis, has been detected in human cells as a result of silver nanoparticle exposure [17]. So far, there have only been a few publications concerning the effect of NPs and mechanism of NPs during the damage of DNA on plant callus culture. NPs did not show any negative effect on banana organogenesis regeneration in vitro [18], while $\mathrm{Fe}_{3} \mathrm{O}_{4}$ NPs slightly affected growth, mitotic index, and dedifferentiation of carrot (Daucus carota L.) in cell culture [19].

Cd QDs have the potential for revolutionizing biological imaging at the cellular level, cancer detection and treatment, radio- and chemosensitizing agents, and targeted drug delivery; however QDs contain substantial amounts of cadmium in a highly reactive form, which is toxic for living organisms [20]. However, recent studies about distribution of cadmium in the chicken embryo of both the solution of Cd ions and solution of CdTe QDs showed that the embryos exposed to the solution of free Cd ions led to the $100 \%$ mortality. On the contrary, the mortality of embryos exposed to QDs was $0 \%$. Obtained results suppose that bioavailability of $\mathrm{Cd}$ in the QDs is significantly lower in comparison to free Cd ions and therefore toxicity is lowered; probably it happens due to the crystalline structure of QDs and due to the capping of the CdTe core [21].

During this study CdS QDs were used because of their nonlinear optical properties, unusual fluorescence behavior, catalytic and transport properties, surface chemistry, and their usage as precursors for nanostructured materials processing [22]. Eruca sativa Mill., commonly known as rocket or rucola, is a leafy vegetable that has anti-inflammatory activity [23]. Additionally, rucola is a fast-growing crop commonly used in phytotoxicity tests [24]. This species is presently grown commercially all over the world. Rucola is also a great source of fibers, minerals, and secondary metabolites such as flavonoids, carotenoids, and ascorbic acid which are known as antioxidants molecules able to scavenge free radicals [25]. Studies also underscore a rich source of glucosinolate compounds in rucola, whose hydrolysis products are giving rocket its characteristic aromas, flavors, and volatiles, what have been consistently linked with anticarcinogenic activity in mammalian tissues [26]. The aim of this study was to evaluate the effect of CdS nanoparticles on the ploidy level and DNA fragmentation in rucola (Eruca sativa Mill.) plants. The results of this work could be important in determining the biocompatibility of different sizes of CdS NPs and in potential agricultural applications of nanoparticles identification. For instance, it might be used for the targeted delivery of hormones, vitamins, antioxidants, herbicides, and insecticides.

\section{Materials and Methods}

2.1. Nanoparticle Characterization. Hydrophobic CdS NPs $(<15 \mathrm{~nm}$ in size) were synthesized at the Institute of Solid State Physics, University of Latvia. Sulfur $(0.1926 \mathrm{~g}, 6 \mathrm{mmol})$ was dissolved in $5 \mathrm{~mL}$ of oleylamine. Separately, $1 \mathrm{mmol}$ of $\mathrm{CdCl}_{2}$ was dissolved in $10 \mathrm{~mL}$ of oleylamine. The $\mathrm{CdCl}_{2}$ solution was heated at $175^{\circ} \mathrm{C}$ for $20-35$ min under $\mathrm{N}_{2}$ flow, and then the oleylamine-sulfur solution was injected under gentle stirring

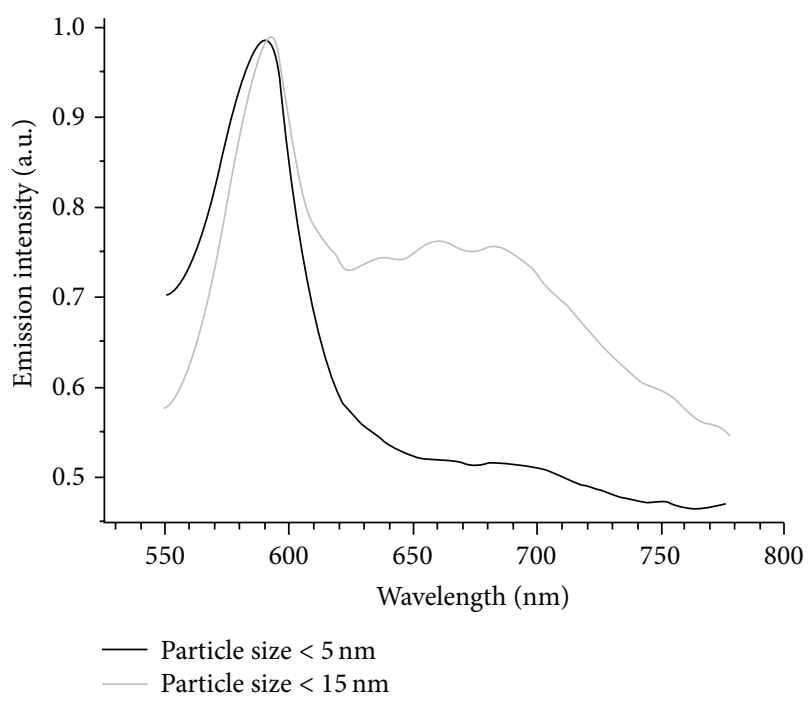

FIGURE 1: Fluorescence spectra of CdS NPs of different sizes. Excitation wavelength $457 \mathrm{~nm}$.

into the hot reaction mixture. The reaction mixture was held at $170^{\circ} \mathrm{C}$ and stirred for $2.5 \mathrm{~h}$ (for NPs with a size range $10-$ $15 \mathrm{~nm}$ ) or $1 \mathrm{~h}$ (for NPs with a size $<5 \mathrm{~nm}$ ) and then naturally cooled down to room temperature. The NPs were separated from the toluene solution by the addition of ethanol and centrifugation.

The fluorescence emission of CdS NPs was measured using a Leica TCS SP5 fluorescence microscope (Leica Microsystems, Mannheim, Germany) in the range 550$800 \mathrm{~nm}$ with excitation at $457 \mathrm{~nm}$. The quantification of the fluorescence intensity was carried out with LASAF software (Leica Microsystems, Wetzlar, Germany). Figure 1 shows the fluorescence spectra of CdS NPs with sizes less than 5 and $15 \mathrm{~nm}$. The spectra had a marked peak at $587 \mathrm{~nm}$ and $593 \mathrm{~nm}$, respectively. The relatively broad fluorescence spectra were explained by the presence of CdS NPs of different sizes.

2.2. Plant Treatment. Seeds of Eruca sativa Mill. (UAB Sēkluva, Vilnius, Lithuania) were sterilized in soap solution for $3 \mathrm{~min}$, rinsed in deionized water, soaked in $0.007 \%$ potassium permanganate for $30 \mathrm{~min}$, rinsed in deionized water, sterilized in 3\% sodium hypochlorite for $20 \mathrm{~min}$, and then rinsed at least five times in deionized, autoclave-sterilized $\left(120^{\circ} \mathrm{C}, 1 \mathrm{~atm}\right)$ water. Seed germination was performed on moistened filter paper in Petri plates, which were placed for 5-7 days in the dark at $25 \pm 1^{\circ} \mathrm{C}$. Then, 100 seedlings were transferred into $5 \mathrm{~mL}$ tubes with deionized water (control samples), 100 seedlings were placed inside the same tubes with deionized water supplemented with CdS NPs with a size $<5 \mathrm{~nm}$, and 100 seedlings were placed into the same tubes with deionized water supplemented with CdS NPs with sizes ranging from $10 \mathrm{~nm}$ to $15 \mathrm{~nm}$. In all cases, the concentration of NPs was $3 \times 10^{-3} \mathrm{~g} / \mathrm{L}$. Tubes with seedlings were placed in the growth chamber at $24^{\circ} \mathrm{C}, 2 \mathrm{Lx}, 16 / 8 \mathrm{~h}$ (day/night) photoperiod, and 80\% humidity. After 15 days of cultivation, the ploidy level and DNA fragmentation were 
assessed. Fluorescent images of the roots and leaves of rucola were taken on a Leica TCS SP5 AOBS microscope (Leica Microsystems, Mannheim, Germany).

2.3. Detection of Cell Ploidy. For the determination of ploidy, approximately $50 \mathrm{mg}$ of leaf tissue was placed in a plastic Petri plate, $0.5 \mathrm{~mL}$ of CyStain UV Ploidy (Partec GmbH, Münster, Germany) was added, and the specimen was chopped with a sharp razor, and then an additional $5 \mathrm{~mL}$ of CyStain UV Ploidy was added and tissues were incubated at room temperature for five minutes. Then, calluses were filtered through a Partec $50 \mu \mathrm{m}$ CellTrics disposable filter and analyzed on Partec CyFlow Space cytometer using UV excitation to detect blue emission. Each measurement was made three times and a minimum of 10000 nuclei was analyzed per sample. As a diploid control, young leaves of a laboratory-grown without Cd QDs (with deionized water) plant of Eruca sativa Mill. were used.

2.4. Mitotic Index. The mitotic index was calculated according to the formula

$$
\mathrm{MI}=4 \times \frac{4 C}{\sum 2 C+4 C},
$$

where $2 C$ and $4 C$ correspond to the mean value of the first (nuclei in G1 phase) and second peaks (nuclei in G2/M phase) obtained. For normal division, $\mathrm{MI}=2.000$. Thereafter, the mean $C$ value of the sample was calculated according to the formula

$$
\text { mean } C \text { value }=\sum_{i=1}^{n} \frac{C_{i} \times N_{i}}{N_{\text {sample }}},
$$

where $N$ is the number of peaks of DNA content in the sample; $C_{i}$ is the $C$ value of nuclei in peak $n_{i} ; N_{i}$ is the number of nuclei in peak $n_{i} ; N_{\text {sample }}$ is the number of nuclei in all peaks of the sample [27].

2.5. Molecular Studies. Genomic DNA was extracted from 300 samples of fresh rucola leaves. Extraction was done with slight modifications using the purification of total DNA from plant tissue Mini Protocol (DNeasy Plant Mini Kit, Qiagen GmbH, Hilden, Germany). The genomic DNA was quantified using a spectrophotometer (NanoDrop 1000, Thermo Scientific, Waltham, USA) to measure absorbance at $260 \mathrm{~nm}$ and the purity of DNA was checked. Stock DNA was diluted to make a working solution of $50 \mathrm{ng} / \mu \mathrm{L}$ for further PCR analysis.

Five RAPD primers, that is, OPA-16, OPA-17, OPB-3, OPB-8, and OPB-18 (Table 1), were selected for the study. PCR reactions were carried out in a thermocycler (Veriti 96Well Thermal Cycler, Applied Biosystems, Foster City, USA). Each $25 \mu \mathrm{L}$ reaction volume contained about $50 \mathrm{ng}$ of DNA template, 1x Taq PCR Master Mix (Taq PCR Master Mix Kit, Qiagen $\mathrm{GmbH}$, Hilden, Germany), and $0.5 \mu \mathrm{M}$ of each primer. The $25 \mu \mathrm{L}$ reaction master mix was prepared as $3 \mu \mathrm{L}$ DNA, $2 \mu \mathrm{L}$ primer, $12.5 \mu \mathrm{L} \mathrm{Taq} \mathrm{PCR} \mathrm{Master} \mathrm{Mix,} \mathrm{and} 7.5 \mu \mathrm{L}$ sterile Millipore water. The thermocycler was programmed
TABLE 1: Sequences of the 10 -mer primers $\left(5^{\prime}-3^{\prime}\right)$ used in the experiments.

\begin{tabular}{lc}
\hline Primer & Sequence \\
\hline OPA-16 & AGCCAGCGAA \\
OPA-17 & GACCGCTTGT \\
OPB-3 & CATCCCCCTG \\
OPB-8 & GTCCACACGG \\
OPB-18 & CCACAGCAGT \\
\hline
\end{tabular}

for an initial denaturation of $3 \mathrm{~min} 94^{\circ} \mathrm{C}$, followed by 35 cycles of denaturation for $30 \mathrm{~s}$ at $94^{\circ} \mathrm{C}, 35 \mathrm{~s}$ of annealing at $38^{\circ} \mathrm{C}$, and $1 \mathrm{~min}$ of extension at $72^{\circ} \mathrm{C}$. The final extension was carried out at $72^{\circ} \mathrm{C}$ for $10 \mathrm{~min}$ with a hold temperature of $4^{\circ} \mathrm{C}$ at the end. RAPD fragments were separated and the product length was detected using the QIAxcel (Qiagen $\mathrm{GmbH}$, Hilden, Germany) capillary automated electrophoresis system.

2.6. Statistical Analysis. Means and standard deviations were detected from three repeated assays of control samples and each treatment. The data obtained was statistically analyzed using the $t$-test at two levels (0.05 and 0.01).

\section{Results and Discussion}

The ploidy in rucola leaves cells was assessed in 300 samples in total and the results were presented in Table 2. The ploidy of cells was detected in control samples, as well as in samples treated with CdS NPs of different sizes. In the control, 94\% of cells were diploid; however, in samples treated with CdS NPs (size $<5 \mathrm{~nm}$ ) the proportion of tetraploid cells and mixoploid $(2 n+4 n)$ cells increased till $15 \%$ and $20 \%$, respectively, and the number of diploid cells decreased till $65 \%$. In samples which were grown on CdS NPs with the larger size, the number of diploid cells increased till $78 \%$ and tetraploid cells till $15 \%$. In this sample, mixoploid cells were not detected. This study acknowledged the tendency to increase for the amounts of polyploid cells in plant if it is treated with NPs. There are lots of researches proclaiming that increase in ploidy leads to improvements in economically valued plants attributes, for example, biomass increase and stress tolerance escalation [28-31].

The mitotic indexes obtained from rucola cells of untreated plants and from plants treated with nanoparticles are presented in Table 3. Results derived that mitotic index values tend to decrease in accordance with the reduction in size of CdS nanoparticles. Normal mitotic index can be seen in samples without any treatment. Reduction in the mitotic index due to nanoparticle exposure was found in previous studies as well. For example, a reduced mitotic index was found in human cells and depended on the time and $\mathrm{TiO}_{2}$ dosage when compared with controls [32]. In plants, decreased mitotic index and an increase in chromosomal abnormalities were observed in onion treated with zinc oxide nanoparticles [33], while silver nanoparticles at a concentration of $50 \mathrm{mg} / \mathrm{L}$ significantly increased the mitotic index in Allium [34]. It is our research group presupposition 
TABLE 2: Determination of the ploidy level in rucola (Eruca sativa Mill.) leaf cells with and without CdS NP treatment.

\begin{tabular}{|c|c|c|c|c|}
\hline \multirow{2}{*}{ Sample } & \multirow{2}{*}{ Number of tested samples } & \multicolumn{3}{|c|}{ Ploidy number of 10000 nuclei, $\%$} \\
\hline & & $2 \mathrm{n}$ & $4 \mathrm{n}$ & $2 n+4 n$ \\
\hline Control & 100 & 94 & 6 & - \\
\hline Plants after treatment with CdS NPs (size $<5 \mathrm{~nm}$ ) & 100 & 65 & 15 & 20 \\
\hline Plants after treatment with CdS NPs (size from $10 \mathrm{~nm}$ till $15 \mathrm{~nm}$ ) & 100 & 78 & 22 & - \\
\hline
\end{tabular}

TABLE 3: Effect of CdS NPs on the mitotic index (MI) of Eruca sativa Mill.

\begin{tabular}{lcrr}
\hline Sample & Number of tested samples & Total examined cells per sample & MI \\
\hline Control & 100 & 10000 & $2.00 \pm 0.1$ \\
\hline Plants after treatment with CdS NPs (size $<5 \mathrm{~nm})$ & 100 & 10000 & $\begin{array}{c}1.14 \pm 0.09 \\
-\mathrm{HS}^{* * *}\end{array}$ \\
\hline Plants after treatment with CdS NPs (size from $10 \mathrm{~nm}$ till $15 \mathrm{~nm})$ & 100 & 10000 & $1.86 \pm 0.07$ \\
$-S^{*}$ & & 1000 \\
\hline
\end{tabular}

${ }^{*} \mathrm{~S}=$ significant at the 0.05 level, ${ }^{* *} \mathrm{HS}=$ highly significant at the 0.01 level.

that the reduction in the mitotic index may have been caused by the effect of CdS NPs on microtubules.

The random amplified polymorphic DNA (RAPD) technique has been successfully used to study genotoxicity in plants [35]. In given study any changes in the genomic DNA amplicon pattern between control samples and samples after treatment with CdS NPs were considered to be genotoxic changes. For the detection of DNA damage caused by CdS NPs, the RAPD assay was applied and results obtained are presented in Table 4. Differences in the DNA banding pattern between control samples and samples treated with CdS NPs were significant and were detected at different places. In the case of primer OPA-16, in control samples, four fragments from $450 \mathrm{bp}$ to $2500 \mathrm{bp}$ were detected. Samples treated with NPs ( $<5 \mathrm{~nm})$ showed two new fragments (600 and $1200 \mathrm{bp})$ and four fragments were eliminated compared with the control, while, in samples treated with larger (10-15 nm) NPs, three fragments were identical with the control and one fragment with a length of $650 \mathrm{bp}$ was eliminated compared to samples without treatment. There were no pattern differences between the control and samples treated with NPs $(10-15 \mathrm{~nm})$ for primer OPB-3; however, the elimination of all fragments detected in control samples was observed in the case of NPs $<5 \mathrm{~nm}$. For primer OPB-8, the DNA assay was also different between control and treated samples. New fragments (550 and $800 \mathrm{bp}$ ) were detected in samples treated with CdS NPs $<5 \mathrm{~nm}$. Samples treated with larger CdS NPs $(10-15 \mathrm{~nm})$ showed only one new fragment $(800 \mathrm{bp})$, while the other fragments were similar to those in samples without treatment. For primer OPB-18, bands with lengths of $550 \mathrm{bp}, 750 \mathrm{bp}$, $800 \mathrm{bp}$, and $850 \mathrm{bp}$ were present in the control samples but could not be found in samples treated with NPs $<5 \mathrm{~nm}$, where two new fragments (200 bp and $250 \mathrm{bp}$ ) were detected. One new fragment with a length of $350 \mathrm{bp}$ was observed in samples treated with NPs $(10-15 \mathrm{~nm})$. There were five bands (400 bp, $550 \mathrm{bp}, 650 \mathrm{bp}, 1700 \mathrm{bp}$, and $1800 \mathrm{bp}$ ) for primer OPA-17 in control samples, whereas only new bands (300 bp
TABLE 4: RAPD profiles from rucola leaves without treatment (control) and treated with CdS NPs.

\begin{tabular}{|c|c|c|c|}
\hline \multirow{2}{*}{ Primers ID } & \multicolumn{3}{|c|}{ Fragment length, bp } \\
\hline & Control & CdS NPs $(<5 \mathrm{~nm})$ & CdS NPs $(10-15 \mathrm{~nm})$ \\
\hline \multirow{6}{*}{ OPA-16 } & 450 & - & 450 \\
\hline & - & 600 & - \\
\hline & 650 & - & - \\
\hline & 1000 & - & 1000 \\
\hline & - & 1200 & - \\
\hline & 2500 & - & 2500 \\
\hline \multirow{3}{*}{ OPB-3 } & 750 & - & 750 \\
\hline & 900 & - & 900 \\
\hline & 1000 & - & 1000 \\
\hline \multirow{4}{*}{ OPB-8 } & - & 550 & - \\
\hline & 650 & - & 650 \\
\hline & - & 800 & 800 \\
\hline & 950 & - & 950 \\
\hline \multirow{7}{*}{ OPB-18 } & - & 200 & - \\
\hline & - & 250 & - \\
\hline & - & - & 350 \\
\hline & 550 & - & 550 \\
\hline & 750 & - & 750 \\
\hline & 800 & - & 800 \\
\hline & 850 & - & 850 \\
\hline \multirow{9}{*}{ OPA-17 } & - & - & 200 \\
\hline & - & 300 & - \\
\hline & 400 & - & 400 \\
\hline & 550 & - & 550 \\
\hline & 650 & - & 650 \\
\hline & - & - & 1100 \\
\hline & - & 1600 & - \\
\hline & 1700 & - & - \\
\hline & 1800 & - & 1800 \\
\hline
\end{tabular}




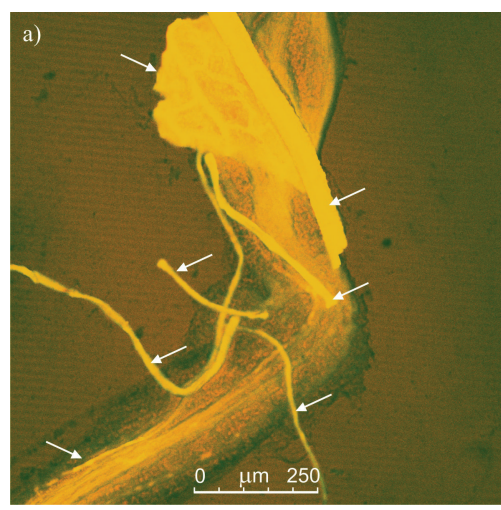

(a)

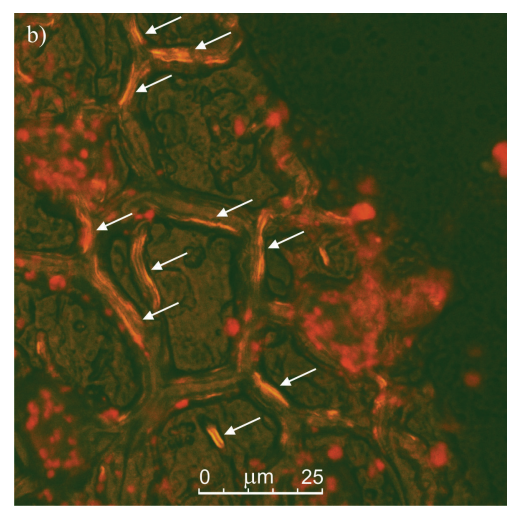

(b)

Figure 2: (a) Fluorescent images of root of rucola. Aggregates of CdS NPs ( $<5 \mathrm{~nm})$ marked by arrows. (b) Fluorescent images of leaf cells of rucola. Aggregates of CdS NPs $(10-15 \mathrm{~nm})$ marked by arrows.

and $1600 \mathrm{bp})$ appeared in samples treated with CdS NPs < $5 \mathrm{~nm}$. However, samples treated with larger CdS NPs (10$15 \mathrm{~nm}$ ) showed two new fragments (200 bp and $1100 \mathrm{bp}$ ) and the absence of the fragment with a length of $1700 \mathrm{bp}$, while the other bands ( $400 \mathrm{bp}, 550 \mathrm{bp}, 650 \mathrm{bp}$, and $1800 \mathrm{bp}$ ) were identical with the control.

These results clearly show that CdS NPs cause changes in the genomic DNA amplicon profile of rucola. Furthermore, marked differences were observed in band manifestation, and the loss of bands or appearance of new bands was detected in samples after treatment with CdS NPs $<5 \mathrm{~nm}$ compared to untreated plants.

Several studies have reported that size is one of the key factors influencing the toxic effect of NPs [36]. The size of NPs is directly correlated to their surface properties, solubility, and chemical reactivity and may affect interactions between nanomaterials and biomolecules; subsequently it influences cytotoxicity and damages DNA [37]. In previous studies, the size-dependent cytotoxicity of silver nanoparticles (Ag NPs) was shown in human lung cells, where the toxicity of small Ag NPs $(10 \mathrm{~nm})$ was associated with the rate of intracellular Ag release, that is, a "Trojan horse" effect [38], while silica NPs of less than $100 \mathrm{~nm}$ induced endocytosisdependent reactive oxygen species generation, DNA damage, and aberrant nucleoplasmic protein aggregation [39]. It was also shown that nanoparticle size is important for overcoming the cell membrane barrier; for example, $\mathrm{TiO}_{2}, \mathrm{ZnO}(30-$ $200 \mathrm{~nm}$ ), and nail-shaped NPs (39-45 nm) can penetrate only the outer layer of the epidermis, while spherical quantum dots (QDs) (15-45 $\mathrm{nm}$ ) are able to reach the epidermis and even the dermis [40]. In studies on Daphnia magna, it was found that small ZnO NPs exert more toxic effects and cause more ultrastructural damage than larger nanoparticles [41]. Other findings indicate that $\mathrm{Ag}$ and $\mathrm{TiO}_{2}$ NPs show genotoxic effects in mammalian cell systems, and this effect is concentration- and size-dependent [42]. The root length and the mitotic cell cycle of Vicia faba were affected by both the size of Ag NPs and the duration of treatment [43]. In previous studies, CdS NPs with an average diameter of $4 \pm 1 \mathrm{~nm}$ were genotoxic in a marine organism [44], while smaller CdS NPs showed a higher degree of bioaccumulation compared to larger NPs, leading to genotoxicity, cytotoxicity, and damage to spermatozoa and other tested organs in mice [45].

The fluorescent images show that, compared to control standard, samples treated with smaller CdS NPs $(<5 \mathrm{~nm})$ demonstrated fluorescence in the yellow-orange region of the spectrum $(580-620 \mathrm{~nm})$ on the root (Figure 2(a)) and on the cell membrane (Figure 2(b)) of plants treated with larger nanoparticles (10-15 nm). The presence of CdS NPs in the extracellular space and inside cells was not observed. This may indicate that NPs of different sizes accumulate on the cell membrane. However, CdS NPs smaller than $5 \mathrm{~nm}$ may be able to diffuse through the membrane and affect the genetic system of the plant, as was observed in this study.

\section{Conclusions}

Our results demonstrate that CdS NPs, especially those $<5 \mathrm{~nm}$ in size, are genotoxic to Eruca sativa Mill. plants. However, the reasons for the observed changes in the genomic DNA amplicon profiles are not clear, but theoretically they could be due to deletions, inversions, translocations, or some other genetic alteration. CdS NPs as a DNA damaging agent have the potential to cause genomic instability. Further characterization of their genotoxicity and especially a clarification of the mechanisms of DNA damage are essential.

In this study, the genotoxic effects of CdS nanoparticles with different sizes were detected. It was found that smaller nanoparticles are more toxic than larger particles at an identical mass concentration.

It was also estimated that CdS NPs of different sizes increased cells ploidy. Unfortunately, on the basis of this study we could not consolidate that ploidy increase leads to changes in agronomic-valued features in rucola. Nevertheless, following discussion of that question is essential; NPs implementation in order to increase the ploidy might become the truly innovative selection method in the future.

Research is in progress to assess additional size ranges of nanoparticles, as well as interactions between different nanoparticles and plants. 


\section{Conflict of Interests}

The authors declare that there is no conflict of interests regarding the publication of this paper.

\section{Acknowledgment}

This work was supported by Project of the European Social Fund no. 2013/0029/1DP/1.1.1.2/13/APIA/VIAA/029.

\section{References}

[1] K. Savolainen, H. Alenius, H. Norppa, L. Pylkkänen, T. Tuomi, and G. Kasper, "Risk assessment of engineered nanomaterials and nanotechnologies-a review," Toxicology, vol. 269, no. 2-3, pp. 92-104, 2010.

[2] N. Ghows and M. H. Entezari, "A novel method for the synthesis of CdS nanoparticles without surfactant," Ultrasonics Sonochemistry, vol. 18, no. 1, pp. 269-275, 2011.

[3] H. Harikrishnan, K. Shine, K. Ponmurugan, I. G. Moorthy, and R. S. Kumar, "In vitro eco-friendly synthesis of cadmium sulfide nanoparticles using heterotrophic Bacillus cereus," Journal of Optoelectronic and Biomedical Materials, vol. 6, no. 1, pp. 1-7, 2014.

[4] P. Kuppusamy, M. M. Yusoff, G. P. Maniam, and N. Govindan, "Biosynthesis of metallic nanoparticles using plant derivatives and their new avenues in pharmacological applications-an updated report," Saudi Pharmaceutical Journal, 2014.

[5] A. R. Santos, A. S. Miguel, L. Tomaz et al., "The impact of CdSe/ZnS Quantum Dots in cells of Medicago sativa in suspension culture," Journal of Nanobiotechnology, vol. 8, no. 1, article 24, 2010.

[6] A. R. Santos, A. S. Miguel, A. Macovei et al., "CdSe/ZnS Quantum Dots trigger DNA repair and antioxidant enzyme systems in Medicago sativa cells in suspension culture," $B M C$ Biotechnology, vol. 13, article 111, 2013.

[7] K. S. Prasad, T. Amin, S. Katuva, M. Kumari, and K. Selvaraj, "Synthesis of water soluble CdS nanoparticles and study of their DNA damage activity," Arabian Journal of Chemistry, 2014.

[8] S. Shukla, A. Jadaun, V. Arora, R. K. Sinha, N. Biyani, and V. Jain, "In vitro toxicity assessment of chitosan oligosaccharide coated iron oxide nanoparticles," Toxicology Reports, vol. 2, pp. 27-39, 2015.

[9] M. H. Lahiani, J. Chen, F. Irin, A. A. Puretzky, M. J. Green, and M. V. Khodakovskaya, "Interaction of carbon nanohorns with plants: uptake and biological effects," Carbon, vol. 81, no. 1, pp. 607-619, 2015.

[10] D. Zhang, T. Hua, F. Xiao et al., "Uptake and accumulation of $\mathrm{CuO}$ nanoparticles and $\mathrm{CdS} / \mathrm{ZnS}$ quantum dot nanoparticles by Schoenoplectus tabernaemontani in hydroponic mesocosms," Ecological Engineering, vol. 70, pp. 114-123, 2014.

[11] M. Filek, M. Zembala, H. Hartikainen et al., "Changes in wheat plastid membrane properties induced by cadmium and selenium in presence/absence of 2,4-dichlorophenoxyacetic acid," Plant Cell, Tissue and Organ Culture, vol. 96, no. 1, pp. 19-28, 2009.

[12] B. Gzyl-Malcher, M. Zembala, and M. Filek, "Effect of tocopherol on surface properties of plastid lipids originating from wheat calli cultivated in cadmium presence," Chemistry and Physics of Lipids, vol. 163, no. 1, pp. 74-81, 2010.
[13] D. A. Navarro, M. A. Bisson, and D. S. Aga, "Investigating uptake of water-dispersible CdSe/ZnS quantum dot nanoparticles by Arabidopsis thaliana plants," Journal of Hazardous Materials, vol. 211-212, pp. 427-435, 2012.

[14] K.-T. Rim, S.-W. Song, and H.-Y. Kim, "Oxidative DNA damage from nanoparticle exposure and its application to workers' health: a literature review," Safety and Health at Work, vol. 4, no. 4, pp. 177-186, 2013.

[15] S. Chowdhury, A. Basu, and S. Kundu, "Green synthesis of protein capped silver nanoparticles from phytopathogenic fungus Macrophomina phaseolina (Tassi) Goid with antimicrobial properties against multidrug-resistant bacteria," Nanoscale Research Letters, vol. 9, article 365, 2014.

[16] C. Krishnaraj, P. Muthukumaran, R. Ramachandran, M. Balakumaran, and P. Kalaichelvan, "Acalypha indica Linn: biogenic synthesis of silver and gold nanoparticles and their cytotoxic effects against MDA-MB-231, human breast cancer cells," Biotechnology Reports, vol. 4, pp. 42-49, 2014.

[17] P. V. AshaRani, G. L. K. Mun, M. P. Hande, and S. Valiyaveettil, "Cytotoxicity and genotoxicity of silver nanoparticles in human cells," ACS Nano, vol. 3, no. 2, pp. 279-290, 2009.

[18] M. N. Helaly, M. A. El-Metwally, H. El-Hoseiny, S. A. Omar, and N. I. El-Sheery, "Effect of nanoparticles on biological contamination of in vitro cultures and organogenic regeneration of banana," Australian Journal of Crop Science, vol. 8, no. 4, pp. 612624, 2014.

[19] L. Giorgetti, M. R. Castiglione, M. Bernabini, and C. Geri, "Nanoparticles effects on growth and differentiation in cell culture of carrot (Daucus carota L.)," Agrochimica, vol. 54, no. 6, pp. 1-9, 2010.

[20] B. A. Rzigalinski and J. S. Strobl, "Cadmium-containing nanoparticles: perspectives on pharmacology and toxicology of quantum dots," Toxicology and Applied Pharmacology, vol. 238, no. 3, pp. 280-288, 2009.

[21] R. Kensova, I. Blazkova, M. Vaculovicova, and V. Milosavljevic, "The effect of cadmium ions and cadmium nanoparticles on chicken embryos and evaluation of organ accumulation," International Journal of Electrochemical Science, vol. 10, no. 4, pp. 3623-3634, 2015.

[22] Z. Q. Mamiyev and N. O. Balayeva, "Synthesis and characterization of CdS nanocrystals and maleic anhydride octene1 copolymer nanocomposite materials by the chemical in-situ technique," Composites Part B: Engineering, vol. 68, pp. 431-435, 2015.

[23] E. Fuentes, M. Alarcón, M. Fuentes, G. Carrasco, and I. Palomo, "A novel role of Eruca sativa Mill. (rocket) extract: antiplatelet (NF- $\kappa$ B Inhibition) and antithrombotic activities," Nutrients, vol. 6, no. 12, pp. 5839-5852, 2014.

[24] C. Vannini, G. Domingo, E. Onelli et al., "Morphological and proteomic responses of Eruca sativa exposed to silver nanoparticles or silver nitrate," PLoS ONE, vol. 8, no. 7, Article ID e68752, 2013.

[25] K. Sultan, M. Zakir, H. Khan, A. Rauf, N. U. Akber, and M. A. Khan, "Biofunctional properties of Eruca sativa Miller (rocket salad) hydroalcoholic extract," Natural Product Research, 2015.

[26] L. Bell, M. J. Oruna-Concha, and C. Wagstaff, "Identification and quantification of glucosinolate and flavonol compounds in rocket salad (Eruca sativa, Eruca vesicaria and Diplotaxis tenuifolia) by LC-MS: highlighting the potential for improving nutritional value of rocket crops," Food Chemistry, vol. 172, pp. 852-861, 2015. 
[27] S. J. Ochatt, "Flow cytometry (ploidy determination, cell cycle analysis, DNA content per nucleus)," in Medicago Truncatula Handbook, p. 13, 2006.

[28] J. C. del Pozo and E. Ramirez-Parra, "Whole genome duplications in plants: an overview from Arabidopsis," Journal of Experimental Botany, vol. 66, no. 22, pp. 6991-7003, 2015.

[29] L. Arvanitis, C. Wiklund, and J. Ehrlén, "Plant ploidy level influences selection by butterfly seed predators," Oikos, vol. 117, no. 7, pp. 1020-1025, 2008.

[30] T. Saminathan, P. Nimmakayala, S. Manohar et al., "Differential gene expression and alternative splicing between diploid and tetraploid watermelon," Journal of Experimental Botany, vol. 66, no. 5, pp. 1369-1385, 2015.

[31] A. S. Mason and J. Batley, "Creating new interspecific hybrid and polyploid crops," Trends in Biotechnology, vol. 33, no. 8, pp. 436-441, 2015.

[32] M. S. Acar, Z. B. Bulut, A. Ateş, B. Nami, N. Koçak, and B. Yıldız, "Titanium dioxide nanoparticles induce cytotoxicity and reduce mitotic index in human amniotic fluid-derived cells," Human and Experimental Toxicology, vol. 34, no. 1, pp. 74-82, 2015.

[33] S. V. Raskar and S. L. Laware, "Effect of zinc oxide nanoparticles on cytology and seed germination in onion," International Journal of Current Microbiology and Applied Sciences, vol. 3, no. 2, pp. 467-473, 2014.

[34] I. M. Prokhorova, B. S. Kibrik, A. V. Pavlov, and D. S. Pesnya, "Estimation of mutagenic effect and modifications of mitosis by silver nanoparticles," Bulletin of Experimental Biology and Medicine, vol. 156, no. 2, pp. 255-259, 2013.

[35] F. Moreno-Olivas, V. U. Gant Jr., K. L. Johnson, J. R. PeraltaVidea, and J. L. Gardea-Torresdey, "Random amplified polymorphic DNA reveals that $\mathrm{TiO}_{2}$ nanoparticles are genotoxic to Cucurbita pepo," Journal of Zhejiang University: Science A, vol. 15, no. 8, pp. 618-623, 2014.

[36] Y.-N. Chang, M. Zhang, L. Xia, J. Zhang, and G. Xing, "The toxic effects and mechanisms of $\mathrm{CuO}$ and $\mathrm{ZnO}$ nanoparticles," Materials, vol. 5, no. 12, pp. 2850-2871, 2012.

[37] H. L. Karlsson, J. Gustafsson, P. Cronholm, and L. Möller, "Sizedependent toxicity of metal oxide particles-a comparison between nano- and micrometer size," Toxicology Letters, vol. 188, no. 2, pp. 112-118, 2009.

[38] A. R. Gliga, S. Skoglund, I. Odnevall Wallinder, B. Fadeel, and H. L. Karlsson, "Size-dependent cytotoxicity of silver nanoparticles in human lung cells: the role of cellular uptake, agglomeration and Ag release," Particle and Fibre Toxicology, vol. 11, article 11, 2014.

[39] Q. Mu, N. S. Hondow, Ł. Krzemiński, A. P. Brown, L. J. C. Jeuken, and M. N. Routledge, "Mechanism of cellular uptake of genotoxic silica nanoparticles," Particle and Fibre Toxicology, vol. 9, article 29, 2012.

[40] M. Jennifer and W. Maciej, "Nanoparticle technology as a double-edged sword: cytotoxic, genotoxic and epigenetic effects on living cells," Journal of Biomaterials and Nanobiotechnology, vol. 4, pp. 53-63, 2013.

[41] N. Santo, U. Fascio, F. Torres et al., "Toxic effects and ultrastructural damages to Daphnia magna of two differently sized $\mathrm{ZnO}$ nanoparticles: does size matter?" Water Research, vol. 53, pp. 339-350, 2014.

[42] G. Apoorva, K. Lavanya, P. Vidisha, R. R. Kumar, Q. Hasan, and D. Ramakrishna, "Genotoxic effects of silver and Titanium dioxide nanoparticles," in Proceedings of the International Conference on Advanced Nanomaterials and Emerging Engineering
Technologies (ICANMEET '13), pp. 133-136, Chennai, India, July 2013.

[43] E. A. Abdel-Azeem and B. A. Elsayed, "Phytotoxicity of silver nanoparticles on Vicia faba seedlings," New York Science Journal, vol. 6, no. 12, pp. 148-156, 2013.

[44] M. Munari, J. Sturve, G. Frenzilli et al., "Genotoxic effects of $\mathrm{Ag}_{2} \mathrm{~S}$ and CdS nanoparticles in blue mussel (Mytilus edulis) haemocytes," Chemistry and Ecology, vol. 30, no. 8, pp. 719-725, 2014.

[45] L. Liu, M. Sun, Q. Li et al., "Genotoxicity and cytotoxicity of cadmium sulfide nanomaterials to mice: comparison between nanorods and nanodots," Environmental Engineering Science, vol. 31, no. 7, pp. 373-380, 2014. 

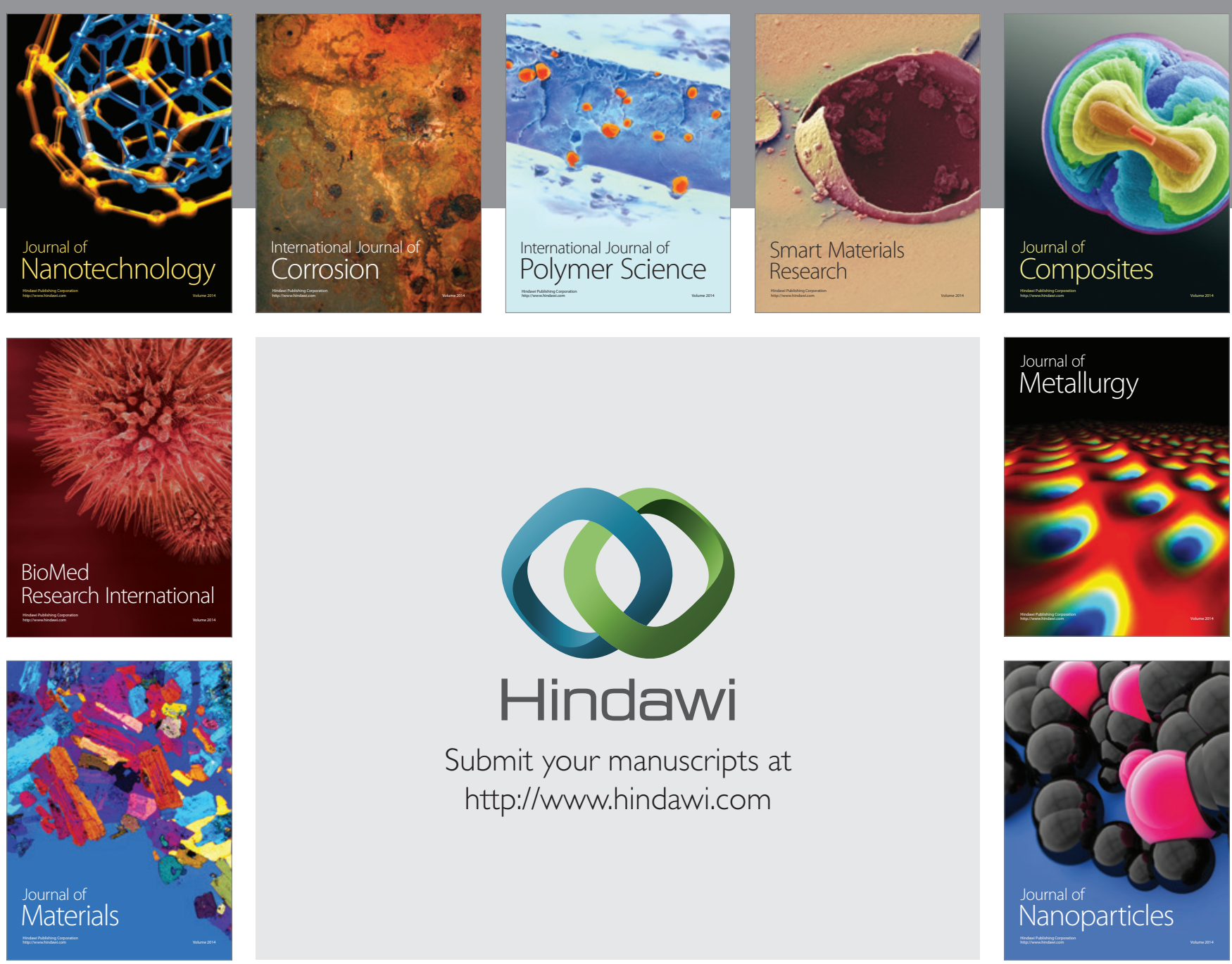

Submit your manuscripts at http://www.hindawi.com
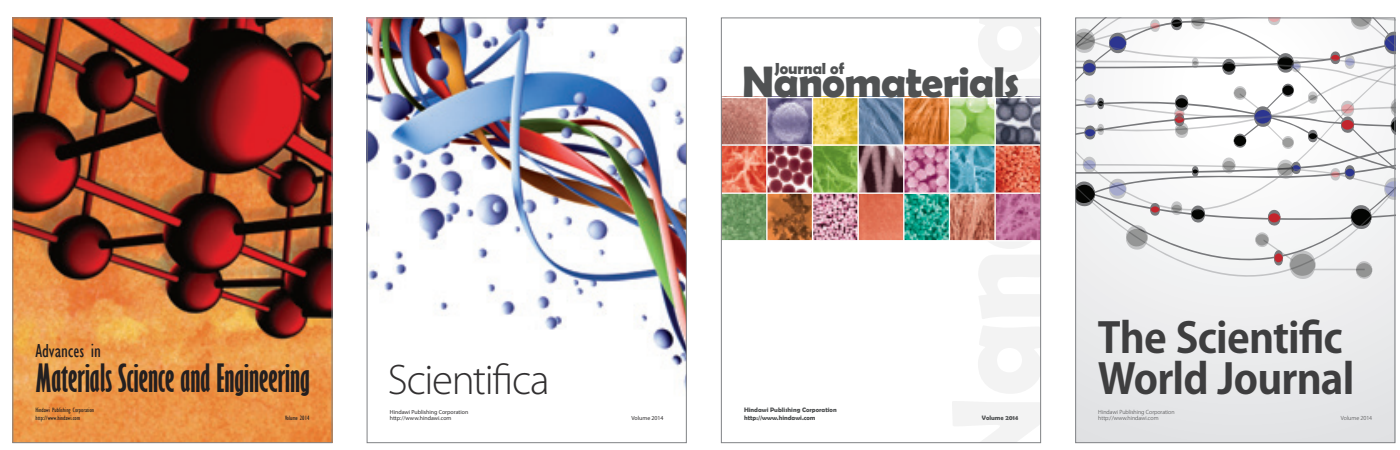

\section{The Scientific World Journal}
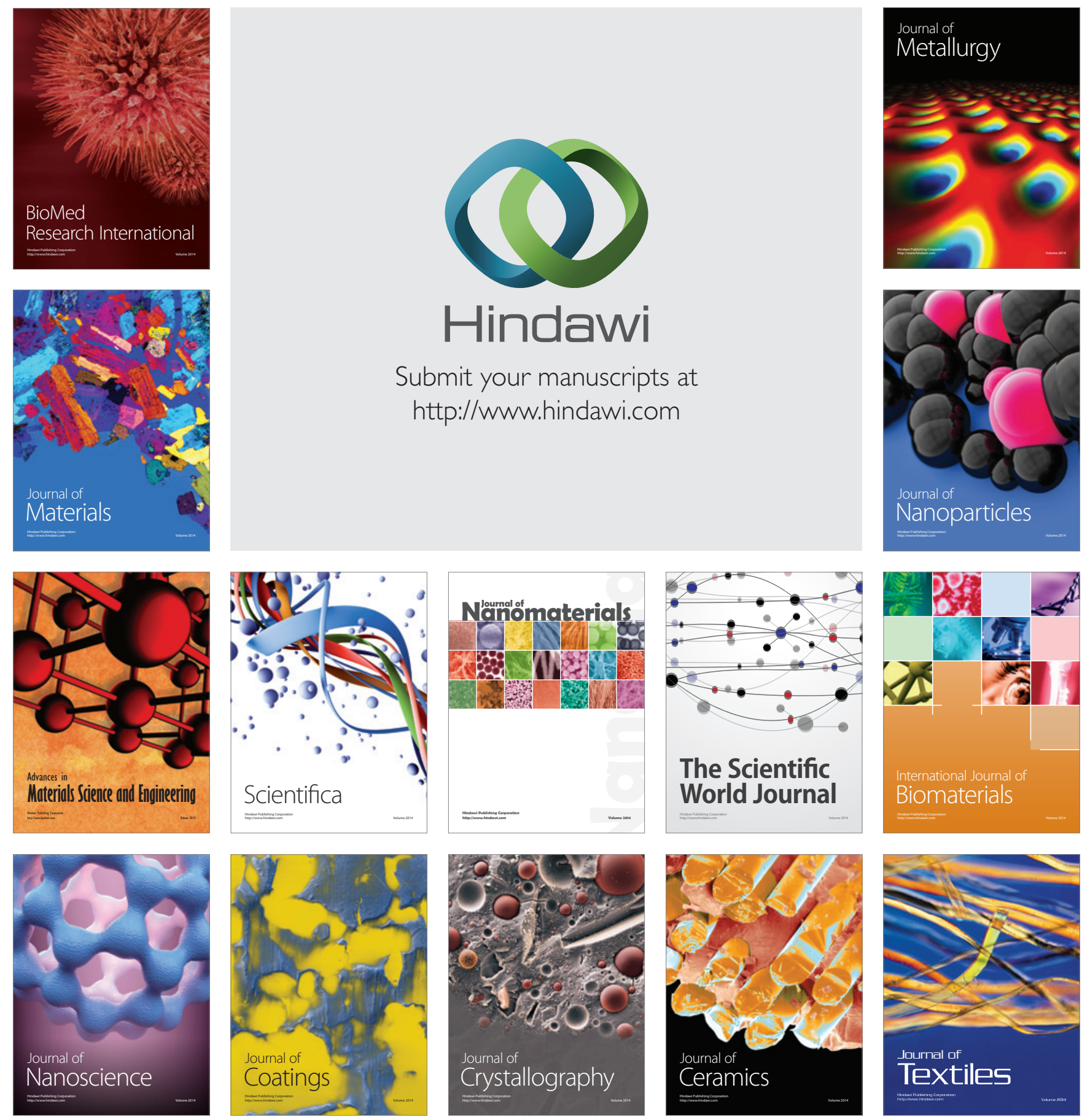